\title{
Damages Scale as a Supporting Tool for Windstorm Early Warning System in Malaysia
}

Mohd Fairuz Bachok ${ }^{1}$, Farah Wahida Mohd Latib ${ }^{2 *}$, Zulfairul Zakariah ${ }^{3}$, Roslan Zainal Abidin ${ }^{4}$, Ponselvi Jeevaragagam ${ }^{5}$ and Sobri Harun 5

${ }^{I}$ School of Civil Engineering, College of Engineering, Universiti Teknologi MARA Cawangan Johor, Pasir Gudang Campus, Johor, Malaysia

${ }^{2}$ School of Civil Engineering, College of Engineering, Universiti Teknologi MARA Cawangan Pahang, Jengka Campus, Pahang, Malaysia

${ }^{3}$ School of Civil Engineering, College of Engineering, Universiti Teknologi MARA Cawangan Pulau Pinang, Permatang Pauh Campus, Pulau Pinang, Malaysia

${ }^{4}$ River Engineering and Urban Drainage Research Center, Engineering Campus, Universiti Sains Malaysia, Pulau Pinang, Malaysia

${ }^{5}$ School of Civil Engineering, Faculty of Engineering, Universiti Teknologi Malaysia, Skudai, Johor, Malaysia

It is a fact that windstorm is a natural disaster that can create enormous damages. Thus, the article aims to serve as a guideline in establishing the damages scale as the supporting tool in the windstorm disaster management. The purpose of the scale is to mitigate impacts of windstorm via early warning system, so that local authorities and public at the affected area are able to know the worst-case scenario if windstorm occurred and could make early preparation in minimising the impacts. The damage scale is established based on the current damage criteria as an early warning of windstorm occurrences was adopted from the damages scale which was established outside Malaysia. On the other hand, there is no damages scale originally established in the country. In order to establish this supporting tool, 51 windstorm occurrences in year 2012 to 2016 from 6 districts in Peninsular Malaysia were selected as a study case and 246 damages were assessed. Besides windstorm damages, gust speed, wind direction, rainfall and radar images as raw data, the study also acquires local conditions wind multiplier map coordinated with meteorological station and overlaid with wind direction map at the study area as well. All the damage locations for each windstorm occurrence will be coordinated in the local conditions wind multiplier map. However, the damages which located underneath the same convective cluster with meteorological station, in position with wind direction and gust speed greater than hazard threshold only will be determined its associated intensity. The scale listed each potential damage according to categories either building, property, or tree. The gust speeds at 1-minute in the scale are between $9.0 \mathrm{~m} / \mathrm{s}$ to $19.3 \mathrm{~m} / \mathrm{s}$. From the study, damages scale has similar hierarchy of level damages with existing damages scale but much lower intensity. Damages scale needs to be continuously updated with a new potential damage especially the damages caused by gust speed greater than $19.3 \mathrm{~m} / \mathrm{s}$, so that the application of the scale can be extended subjected to more windstorm occurrences and affected areas. This ensures that the scale is applicable to be used in the country throughout the time.

Keywords: damages scale; early warning system; supporting tool; windstorm 


\section{INTRODUCTION}

Thunderstorm's such as downbursts and tornadoes are natural disasters which are capable of causing damages to properties and losses of life. These extreme meteorological disasters which are also known as global phenomena since it can occur at any places and time in the world. This phenomenon occurs during short period of time with high order of randomness in space and time and absolutely it is a local event (Lee et al., 2017). In Malaysia, windstorms can be expected each year, windstorm occurred throughout the year, most of the districts experience windstorm and most of the windstorms have short time of life cycle which last less than 30 minutes (Mohd Fairuz et al., 2012). In Europe country, windstorms are considered as the major disturbance to forest ecosystems as reported by Fortin et al. (2014) \& Schelhaas et al. (2003). Hung (2010) reported that the global warming that happened in Southeast Asia will change the storm characteristic.

The increasing of windstorm event in Malaysia and entire world will lead to loss of public and private properties and also cause fatality as mentioned by Zakaria et al. (2019). According to reports from mass media, windstorms not only damage building (house collapsed and roof blown off), properties (power pole brought down and canopy blown away) and tree (trunks snapped and uprooted) but also could possibly extend to secondary damages such as cause injury, claim live to humans and destroy vehicles. This is due to the fallen trees and flying objects.

Thus, some approaches have been developed in order to mitigate the aftermath of these disasters. One way is by producing a scale which is classified the intensity of the events with potential damages. Currently, the most wellknown damages scales related to wind are Beaufort scale (Burroughs et al., 2003), Fujita scale (Fujita, 1971), TORRO Tornado Intensity scale (Meaden, 1976) and Enhanced Fujita or EF-scale (Potter, 2007). The damages scales distinguish various levels of damages according to wind speed.

A scale could provide beneficial information to the public in evaluating the impacts from meteorological events of a particular magnitude that may have or had potential damage on the life and property of humans (Zielinski, 2002). The scheme will describe and summarise the events characteristics, so that it becomes much easier to evaluate.
This is due to an event that may often be complex in their formation and behaviour. In particular, the scheme is a supporting tool that can be used in risk assessment process by forecasters to warn the public. Frequency and severity of windstorm impacts of the events can only be determined through risk assessment process from hydro-meteorological information and tools (Auld, 2010).

Scale for tornado or straight-line wind that relates to intensity and potential damages provides many benefits. Even though, there are Beaufort scale, Fujita scale, TORRO scale and even EF-scale which had been established many years ago, however these damages scales were not applicable to be used in the country due to differences in construction since existing damages scales was established outside Malaysia. Differences in construction between countries such as construction practices, building resistances, building materials and types are the deterrent factors (Dessens \& Snow 1989; Doswell et. al., 2009; Webb et al., 2009). Their use has also been discouraged in other countries except in the countries where the scales were developed. Countries outside USA should develop their own method even by following developing enhanced Fujita scale (Doswell et al., 2009).

Several windstorm occurrences that caused damages to the building, property and tree, show that criteria of delivering the warnings have to be improved. Existing criteria of classifying wind speed, those above $50 \mathrm{~km} / \mathrm{h}$ are categorised as severe storm which could contribute to hazard. However, according to MET Malaysia reports show that wind speed below $50 \mathrm{~km} / \mathrm{h}$ could also damage houses, uproot trees, and blow off roofs. Windstorm damages that had taken place in Malaysia actually did not met any established criteria or scale of wind speeds. A series of tornadoes which occurred in Kedah that causes the damages were the tornado with intensity only equivalent to $30 \mathrm{~km} / \mathrm{h}$ (Adila, 2015).

Rainfall that associates with strong wind during windstorm also can enhance the effects of damages (Kanak et al., 2007). For example, rainfall causes the land to be wet and this makes trees much easier to be uprooted than just break at a certain wind speed. TORRO scale at code To states that trees will break at the wind speed $21.5 \pm 3.5 \mathrm{~m} / \mathrm{s}$ but on wet unstable soil, tree will be uprooted. As reported by Freitas \& Dias (2013), on February 15-16, 1941 a strong windstorm (usually referred as the 1941 cyclone) hit Iberian Peninsular that 
caused shipwrecks, coastal villages flooding and major coastal morphological modifications. Other examples include broken windows and sliding doors due to wind loads that cause water penetration into the buildings and damage the interiors of houses. This damage was experienced at Guam Reef Hotel, Guam on September 16th, 1997 (Houston et al., 2002).

In Malaysia, a classic example of rainfall damages was reported through the media on December 18th 2004 in Alor Gajar, July 18th 2003 in Kota Tinggi and 24th May 2004 Baling, as home appliances and house interiors were destroyed as strong wind damaged the roofs of houses. Roof materials were either blown away or were ripped off during the windstorm occurrences. As a result, existing criteria should be revised according to damages in Malaysia and enhance by not only wind/gust parameter alone but the rainfall parameter.

On the other hand, the damages scale acts as supporting tool for the early warning system. Effective early warning is a system which not only issue a timely warning and possible hazards that could possibly occur at the suggested time but also location and the intensity (Khairulmaini, 2007).

\section{MATERIALS AND METHOD}

The basic steps in establishing this supporting tool to manage disasters especially windstorms include collecting windstorm occurrences, designing damages survey, coordinating, and assessing the damages, and establishing the windstorm damage scale.

\section{A. Collection of Windstorm Occurrences}

Damages from windstorm occurrences were collected from meteorological station in the nearest district. This is because data received from meteorological station contribute as observational data for this study and thus, needs to be tested run. The main sources of occurrences were from mass media, and reports from government agencies such as Department of Social Welfare and local authorities. Location, date, time, and damages are the details that need to be recorded for each occurrence. There are 51 in year 2012 to 2016 across six districts in Peninsular Malaysia namely Kulai, Johor Bahru,
Kuantan, Kuala Terengganu, Kota Setar and Perlis which has been selected for this case study.

However, since the details of the windstorms were collected via sources such as mass media and reports from local authority, there is possibility that some of the information gathered were not accurate, especially subjects to time and date of the occurrences. For example, mass media often reports without specifying the date of the occurrence but were more likely to generally, for example 'today', 'yesterday', '2 days ago' or state any day in broadly, for instance like 'Sunday'.

This will lead to confusion on the exact date because the same report has the possibility of being released either on the same date or later via online or physical newspapers. Correspondingly, reports which involved numerous victims are lacking consistency.

Victims have reported varied dates for the cases of windstorm occurrences to the authorities. More concerning case would be that victims failed to remember exact dates or were not even present during the occurrences.

Additionally, another matter of concern is that although the study only focused on windstorm occurrences which take place nearby a meteorological station, but not all are able to record each meteorological data. This is because the location of the convective cloud which produced the windstorm is far from the location of the meteorological station.

Thus, in order to overcome this confusion, time series of 1minute gust speed for 24 hours duration which was reported on the day of the occurrence, the day before and a day after being reported must be examined. If there is a series of gust speed ascending drastically in a short time (anomaly) as shown in Figure 1, this shows that windstorm has occurred on that day as reported. Rapid accelerating wind with preceding velocity is often not apparent unless gust occurs. (Sallis et al., 2011). Gust come quickly, occur suddenly, and then end as abruptly as they began.

By examining the gust speed, time of the windstorm occurrences could also be ascertained. However, if no series of gust speed anomaly were reported on the day, thus time series of the day before must be examined. If there still no recorded occurrences, then the time series of the day after must be examined. Finally, if there was no series of gust speed 
anomaly on all the three days, the windstorm occurrence will not be considered.

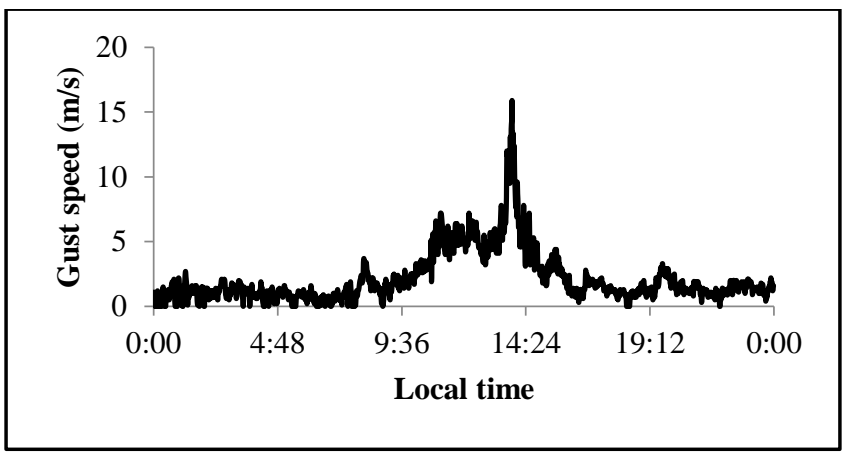

Figure 1. Gust speed anomaly during windstorm occurrence

\section{B. Designation of Damages Survey}

The survey was designed by adoption the windstorm surveys produced by National Oceanic and Atmospheric Administration (NOAA). The survey also included the damages that were listed in existing scales which were caused by windstorms in Malaysia from mass media. Damages indicators are categorised according to MS1759:2004. The purpose of this survey is to serve as a tool to control consistency in assessing windstorm damages. Consistency is one of the characteristics that require thoughtful consideration of the trade-offs to produce a good rating since it may remove secular trends from the database (Doswell et al., 2009).

\section{Coordination of Windstorm Damages}

All the damages identified will be coordinated in the Google Earth Pro map. The damages also will be categorised according to the types of damages which are effects to building, structures, property, or tree because existing damage scales categorised physical damage into the three major groups namely building and structures, property, or tree (Figure 2). Moreover, this has liaised with major groups of damage indicators in EF-scale.

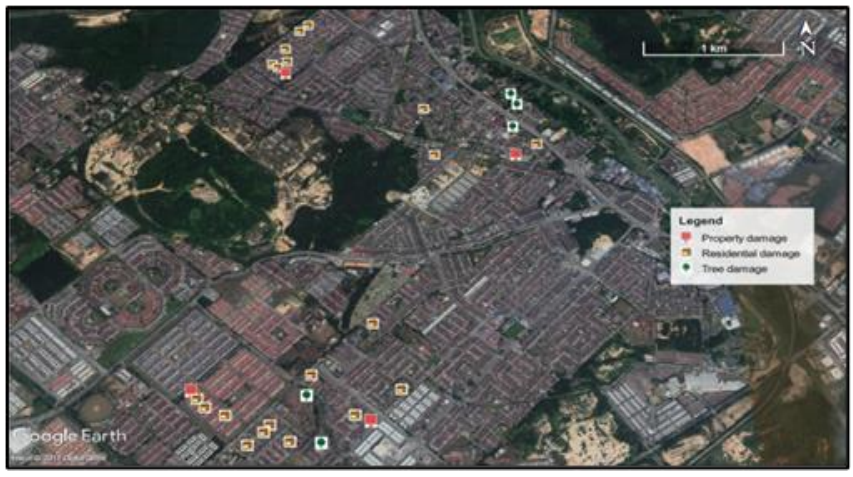

Figure 2. Location of damages at affected areas according to three major groups (building, property, and tree) in Google Earth map during windstorm occurrences on April 14th, 2012, at Johor Bahru district (study case: JB42)

\section{Assessment of Damages}

The damages from each study windstorm occurrences will be assessed by examine the report and photo. Then, these damages will be further assessed, and cross checked by using Google Map Street View to get a clearer picture of the damages. However, damages without any detail or photo available either in reports from local authorities, mass media or Google Map Street View locations of the windstorm occurrences will be revisited to conduct damages survey onsite along with its photographic and video documentation.

Since this survey of damages was done after a period of several years, it is possible that most of these damages have been repaired. Then, only damages which have not been repaired or damages with evidence that showing they have been repaired will be assessed (Figure 3). Without these two features, damages which have been reported will not be assessed. The damages assessed in the study are as shown in Table 1.

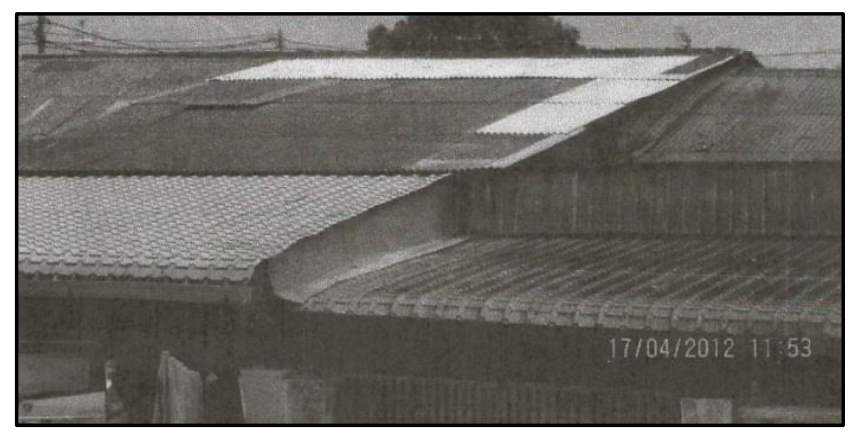

Figure 3. Damages that have been repaired 
Table 1. Physical damages assessed in the study

\begin{tabular}{ccc}
\hline Category & Sub-category & Damages (no.) \\
\hline & Apartment & 1 \\
& Institutional & 3 \\
& building & \\
& Garage & 4 \\
Building & Low rise building & 5 \\
& Porch & 2 \\
& School & 2 \\
& Public house & 42 \\
& Small retail & 2 \\
& Surau & 2 \\
& Warehouse & 1 \\
& Wooden house & 96 \\
\hline \multirow{6}{*}{ Property } & Awning & 4 \\
& Canopy & 4 \\
& Flagpole & 2 \\
& Fence wall & 1 \\
& Stall & 2 \\
& Signboard & 3 \\
& Walkaway & 2 \\
\hline Tree & - & 68 \\
\hline
\end{tabular}

\section{E. Establishment of Windstorm Damages Scale}

The damages scale is established by adopting available windstorm classification schemes with slight modification by adding parameters for rainfall. Cumulative rainfall is measured during rainfall events that were separated from other rainfall periods more than 6 hours until the time of maximum gust speed (Roslan \& Hui 1995). Classification of cumulative rainfall is based on Table 1 . To measure the intensity of windstorm-producing thunderstorms in this damages scale, either both gust speed and cumulative rainfall or gust speed.

Before determining the intensity associated with potential damages and then establishing the damages scale, the two tasks that are critical were the identification of relevant windstorm occurrence and determining its damages. The relevant windstorm occurrence is the occurrence with maximum gust speed which exceeds the minimum gust speed that could cause damages and during this period, there is convective cluster above the meteorological station. On the other hand, the maximum gust speed which was recorded is subjected to the strong wind released from a downdraft that was produced from the convective cluster above the meteorological station.
Whereas relevant damages are damages that are caused by related windstorm occurrence during the maximum gust speed and in position of the wind direction (Figure 4 and Figure 5). Damages that are underneath the convective cluster that are above the meteorological station are considered to have received the same maximum gust speed as recorded by the meteorological station. ... This is taking into consideration that the downdraft was produced from the same convective cluster. Basically, the damages that are located underneath the same convective cluster with the meteorological station and in position with the wind direction by which its gust speed is greater than the minimum gust speed that could cause damages are the only damages to be considered in the establishment of damages scale.

In summary, step by step establishment of damages scale are as follows:

a) Damages coordinated in Google Earth Pro map

b) Damages have been assessed according to damages survey and through reports and photos from the mass media, government agencies and local authorities, Google Street View and on site

c) Time of maximum gust speed is determined through the time series of gust speed every 1-minute.

d) Radar images during the time of maximum gust speed overlaid in Google Earth Pro map have been coordinated damages in advance.

e) Wind direction map overlaid in Google Earth Pro map have been coordinated damages and overlaid radar images in advance

f) Wind direction of gust speed that is greater than the minimum gust speed that could cause damages were identified through time series of gust speed and wind direction for every 1-minute

g) Relevant damages were identified as study damages through observation on Google Earth Pro map.

h) Damages were coordinated in local conditions wind multiplier map to determine local conditions multiplier.

i) Gust speed recorded on meteorological station for each damage will be multiplied by the local condition multiplier for the actual value of gust speed.

j) Cumulative rainfall until time of maximum gust speed also will be determined through time series of rainfall for every 1-minute. 
k) Similar types of damages of different windstorm occurrence will be compared to get the lowest intensity.

1) Lowest intensity is the lower bound intensity for each type of damages.

m) Damages scale will be arranged according to hierarchy of the highest along with its potential damages to the lowest intensity.

Table 2. Classification scheme for rainfall intensity

\begin{tabular}{cc}
\hline Class & Rainfall intensity $(\mathbf{m m} / \mathbf{h r})$ \\
\hline Not traceable & - \\
Light rain & $1-10$ \\
Moderate rain & $11-30$ \\
Heavy rain & $31-60$ \\
Very heavy rain & $>60$ \\
\hline Source: Malaysia Department of Irrigation and Drainage \\
2011
\end{tabular}

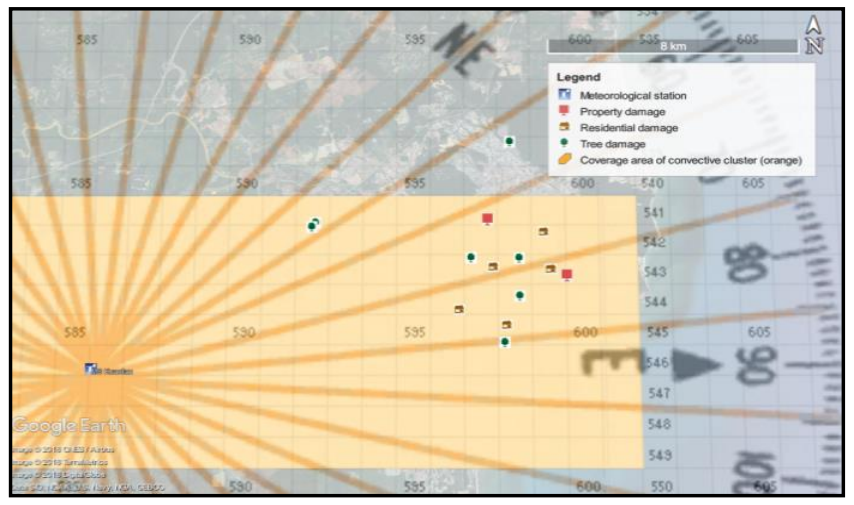

Figure 4. Relevant damages are damages located underneath convective cluster and in position with wind direction of the gust speed which higher than hazard threshold (study case: $\mathrm{KN} 30$ )

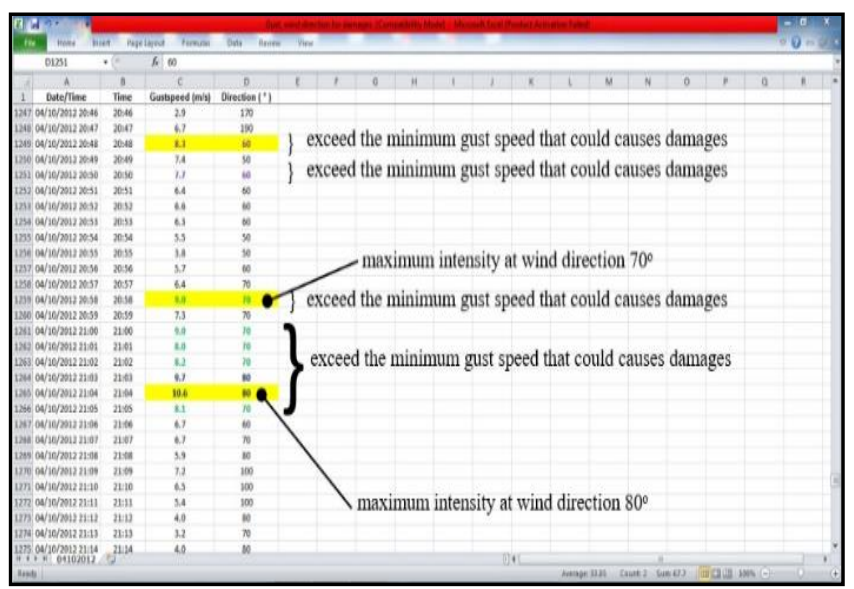

Figure 5. Gust speed to establish hazard threshold and damages scale, only gust speed which exceeds the minimum speed which could cause damages were considered.

\section{RESULT AND DISCUSSION}

Damages scale needs to be developed in the country due to the differences in construction and environment of the country in the country. Hazard threshold which was different between European countries and the establishment of TORRO scale for European countries and F or EF-scale for USA had proven this matter. Hence, this indicates that each country including Malaysia needs to develop its own hazard threshold and damages scale.

Damages scale which was established according to the analogy of the Beaufort, $\mathrm{F}$ or EF and TORRO scale relates between intensity (wind or gust speed) with potential damages sorted by different hierarchy. However, it tends to follow EF-scale which adds additional damage indicators consisting of types of buildings (e.g., mall), structures (e.g., tower) and trees (e.g., hardwood). The additional damage indicators will lead to more consistent ratings of intensity since an expected, upper, and lower bound wind speed will be well defined for each degree of damages (McDonald et al., 2009).

However, two amendments were made, the first amendment is no upper bound for the potential damages and its associated intensity and the second amendment is to add the cumulative rainfall parameter as an additional parameter for damages to tree (uprooted tree) and property inside the building. First amendment is intended to make known clearly the intensity for all the listed damages through information of the lowest intensity that could cause damage for each listed damage in damages scale, then severe damages with the increasing of the intensity.

Upper bound will tend to focus on the damages at its hierarchy level only and will likely not consider the damages even though at that particular intensity the windstorm is capable of causing damages to lower hierarchy level. In addition, actual intensity can only be determined with highly precision by the lower bound of intensity compared to the upper bound. This is due to the difficulty in determining intensity associated with the high-end damages.

There is no evidence at the upper end of the F-scale which refers to the relationship between duration of the wind and damages produced.

Taking into consideration the EF-scale which sets no upper bound for $\mathrm{EF}_{5}$ is to avoid people from making assumption 
that the intensity at upper bound is the worst-case scenario which denotes that the intensity level could not have moved beyond this level and damages will not occur, even though the extent of the intensity limit never been finalised until to date. Intensity range associated with damages is still doubtful in its accuracy, particularly in the upper bound of intensities (Feuerstein et al., 2011).

Second amendment was made because there is evidence proven that the uprooted tree damage was caused not only by the actions of strong wind but also influenced by the quantity of water in the soil. The amount of rainfall was also can affect the strength of the root system in a tree. Prolonged heavy rainfall can weaken the holding power of a tree's root system, making it easier for the tree to fall (Bunting \& Smith 1993).

TORRO scale categorises and differentiates tree damages between trees on stable and wet soil which could be uprooted by less magnitude of windstorm in comparison to trees which are unstable and dry soil. This was taken into consideration as the effects of physical damage of the trees is similar to the type of damage listed in the existing damages scale.

Besides the amendments on damages scale, other amendment was made on the method of assessing the intensity of damages where not only by recording the maximum wind speed that was recorded by the meteorological station near the location of the damages during windstorm occurrences alone but also through observation by using the radar imagery and wind direction. Intensity was also associated with the damages that occurred underneath convective cluster which produced downdraft and above the meteorological station which exceeds the minimum speed of gust speed time.

This can be identified through radar echoes imageries. The purpose is to determine the intensity associated with damages with the assumption that the damages and meteorological stations experienced intensity of downdraft from the same resource. Then, by referring to a time series of wind direction, the damages under the convective cluster which is in positioned with the wind direction during the gust speed and exceed the minimum gust speed that could cause damages were determined. Thus, intensity associated with the damages is the highest intensity observed from the intensity time series graph.
Through this approach, it also can be confirmed that damages caused by strong downdraft were produced from convective cluster above the meteorological station but not from the other convective clusters near the meteorological station and above the meteorological station. It must be known in order to prevent errors in determining the intensity associated with damages due to the wrong selection of convective cluster since the intensity of occurrences depends on the convective cluster attributes.

Moreover, the wind direction would provide associated intensity more precisely because it does not solely depend on the maximum intensity but also the intensity based on the wind direction and the position and location of the damages. All intensity was determined by similar approach except uprooted trees which needed additional variables, such as cumulative rainfall that was determined through the rainfall time series.

There is a difference between associated intensity of the same damage due to differences in gust speed recorded and conditions of the area where the damage was located. Lowest intensity is the lower bound intensity for each damage (Table 3 and Table 4). Table 5 and Table 6 show the damages scale of the lower bound intensity for each damage according to its structural, building, property, and tree, respectively. While Table 7 is a damage scale that has been combined and simplified between Table 5 and Table 6 .

The scale is not a finalised scale and can be enhanced especially when there is an intensity lower than intensity of listed damages that been determined in the future or there is damage that is not yet listed in this scale. This is due to the fact that damages scale deals with ways of life and needs of a living since buildings require modification, building codes change and new technologies emerge through time (Blong, 2003).

Designing of land conditions wind multiplier map is needed prior to creating this scale for its establishment is heavily reliant on this supporting tool. The scale will further scrutinise the possible risks that may be experienced by the public or local authorities as well if windstorm occurred. This will lead in decision making by public and local authorities whether to act or not in response to the warning because they can find out whether the forecasted windstorm could potentially damage their surrounding or not. 
The damages listed in the scale is similar to the damages listed in the scale is similar as the damages listed in Beaufort, $\mathrm{EF}$ or $\mathrm{F}$ and TORRO scale which is are listed according to the intensity from low to high intensity. This indicated that the approach used to establish the damages scale is practical, even though there is a difference between the intensity. The intensity recorded on the damages scale is much lower as the maximum of intensity recorded is $69.5 \mathrm{~km} / \mathrm{h}$ compared to existing damages scale such as EF or F-scale $(513 \mathrm{~km} / \mathrm{h})$ and TORRO scale $(482 \mathrm{~km} / \mathrm{h})$. Besides the difference in terms of construction and intensity associated with damages that take into account the 1-minute gust speed, another factor that causes damages in Peninsular Malaysia is the thunderstorm by-products or also known as downburst. Downburst especially microburst is very common, but most are not severe (Wakimoto, 2001).

This is what differentiates this scale to EF or F and TORRO scale which focus on the damages caused by the tornado. On the other hand, microburst Is considered as less severe by countries like USA since most of microburst intensity does not cause significant damages. However, in Malaysia, microburst should be considered differently. As evidence, based on the EF-scale and TORRO scale, roof damages will only occur with windstorm intensity of at least $64.0 \mathrm{~km} / \mathrm{h}$ or $61.0 \mathrm{~km} / \mathrm{h}$, respectively, but based on the damages scale, roof damages could even happen with an intensity of $32.4 \mathrm{~km} / \mathrm{h}$ or slightly higher if converted according to 3 -seconds gust speed.

Moreover, a structure of a high-rise building collapsed at Penang in year 2013 is caused by wind with the speed equal to $17.46 \mathrm{~m} / \mathrm{s}(62.9 \mathrm{~km} / \mathrm{h})$ (Deraman et al., 2014). When compared using the damages scale, the intensity associated to damages with findings from previous studies in Peninsular Malaysia, it shows that the damages are recorded to have occurred from equal range of intensity. Wind speed damage listed on this scale is according to the intensity range of the same surrounding. This reinforced that the damages scale is compatible with the construction and surrounding in this country.

Table 3. Typical intensity associated with physical damages for each windstorm occurrence (e.g., wooden house damaged truss - wood)

\begin{tabular}{cc}
\hline Windstorm code case & Intensity (m/s) \\
\hline $\mathrm{JB} / 42$ & 14.6 \\
$\mathrm{KN} / 32$ & 12.0 \\
$\mathrm{CH} / 16$ & 11.8 \\
$\mathrm{CH} / 2 \mathrm{O}$ & 11.4 \\
$\mathrm{KS} / 3$ & 10.6 \\
$\mathrm{KS} / 3$ & 9.0 \\
\hline
\end{tabular}

Table 4. Typical intensity associated with tree damages for each windstorm occurrence (e.g. Batai Laut (Peltophorum Pterocarpum) - tree uprooted)

\begin{tabular}{ccc}
\hline $\begin{array}{c}\text { Windstorm } \\
\text { code case }\end{array}$ & $\begin{array}{c}\text { Intensity } \\
(\mathbf{m} / \mathbf{s})\end{array}$ & $\begin{array}{c}\text { Rainfall } \\
(\mathbf{m m})\end{array}$ \\
\hline $\mathrm{JB} / 42$ & 19.3 & 0.0 \\
$\mathrm{KT} / 25$ & 12.8 & 3.2 \\
$\mathrm{KN} / 32$ & 12.0 & 13.4 \\
\hline
\end{tabular}

Table 5. Physical (building, structures and property) damages in damage scale

\begin{tabular}{lll}
\hline Intensity (m/s) & & Potential physical (building, structures, and property) damages \\
\hline & - & Warehouse building - loss of roof covering material - metal \\
& - & Walkway - loss of roof covering material - tile \\
& - & Walkway - loss of roof covering material - polycarbonate \\
19.3 & - & Low rise building - loss of roof covering material - metal \\
& - & Institutional building - window damaged - glass \\
& - & Institutional building - loss of roof covering truss - tile \\
& - & Collapse of flag poles-composite \\
& - Small retail building - loss of roof covering material - tile \\
& - Small retail building - collapse of plaster ceiling - gypsum \\
& - School - loss of roof covering material - tile \\
& - School - damaged truss - wood \\
& & Public house - window damaged - glass \\
\hline
\end{tabular}




\begin{tabular}{|c|c|}
\hline & $\begin{array}{ll}\text { - } & \text { Public house - loss of roof covering material - tile } \\
\text { - } & \text { Public house - damaged truss - wood } \\
\text { - } & \text { Public house - damaged truss - metal } \\
\text { - } & \text { Damaged awning - metal }\end{array}$ \\
\hline 12.2 & $\begin{array}{ll} & \text { Apartment }- \text { damaged roof }- \text { tile } \\
\text { - } & \text { Small retail building }- \text { damaged roof }- \text { tile } \\
\end{array}$ \\
\hline 10.6 & $\begin{array}{ll}\text { - } & \text { Wooden house - collapse of exterior wall - wood } \\
\text { - } & \text { Wooden house - loss of roof covering material - asbestos } \\
\text { - } & \text { Public house - loss of roof covering material - zinc } \\
\text { - } & \text { Collapse of canopy - pyramid }\end{array}$ \\
\hline 9.7 & $\begin{array}{ll}\text { - } & \text { Public house - loss of roof covering material - asbestos } \\
\text { - } & \text { Public house - damaged roof - tile } \\
\text { - } & \text { Public house - collapse of plaster ceiling - gypsum } \\
\text { - } & \text { Porch - loss of roof covering material - zinc } \\
\text { - } & \text { Porch - loss of roof covering material - metal } \\
\text { - } & \text { Porch - loss of roof covering material - asbestos }\end{array}$ \\
\hline 9.0 & $\begin{array}{ll}\text { - } & \text { Wooden house - loss of roof covering material - zinc } \\
\text { - } & \text { Wooden house - damaged truss - wood }\end{array}$ \\
\hline
\end{tabular}

Note: 1-minute gust speed, $10 \mathrm{~m}$ height

Table 6. Potential physical (tree) damages in damage scale

\begin{tabular}{|c|c|c|c|}
\hline $\begin{array}{l}\text { Intensity } \\
\quad(\mathrm{m} / \mathrm{s})\end{array}$ & $\begin{array}{l}\text { Cumulative } \\
\text { rainfall } \\
(\mathbf{m m})\end{array}$ & Physical (tree) & Damages \\
\hline 19.3 & - & $\begin{array}{l}\text { - } \text { Ara Jejawi (Ficus Microcapra) } \\
\text { - } \quad \text { Batai Laut (Peltophorum Pterocarpum) } \\
\text { - } \quad \text { Pisang Kipas (Revenala Madagascariensis) }\end{array}$ & Tree uprooted. \\
\hline 17.4 & 2.0 & - $\quad$ Tanjung (Mimusops Elengi) & Tree uprooted \\
\hline 17.2 & 0.4 & - Angsana (Pterocarpus Indicus) & Tree uprooted \\
\hline 16.2 & - & $\begin{array}{ll}\text { - } & \text { Balik Angin (Mallothus Biaceae) } \\
\text { - } & \text { Penaga Laut (Calophyllum Inophyllum L) }\end{array}$ & $\begin{array}{l}\text { Trunks snapped } \\
\text { Trunks snapped }\end{array}$ \\
\hline 14.6 & - & $\begin{array}{l}\text { - } \text { Akasia (Acacia Mangium) } \\
\text { - Hujan-hujan (Samanea Saman) } \\
\text { - Ketapang (Terminalia Catappa) } \\
\text { - Tecoma (Tabebuia Pentaphylla) }\end{array}$ & Tree uprooted \\
\hline 12.8 & 3.2 & $\begin{array}{ll}\text { - } & \text { Batai Laut (Peltophorum Pterocarpum) } \\
\text { - } & \text { Keranji (Dialium Kingii Prain) } \\
\text { - } & \text { Rhu (Casuarina Equisetifolia) } \\
\text { - } & \text { Tecoma (Tabebuia Pentaphylla) } \\
\text { - } & \text { Tembusu (Fagrea Elliptica) } \\
\end{array}$ & Tree uprooted \\
\hline 12.0 & 13.4 & $\begin{array}{l}\text { - } \text { Akasia (Acacia Mangium) } \\
\text { - } \quad \text { Batai Laut (Peltophorum Pterocarpum) } \\
\text { - } \quad \text { Rhu (Casuarina Equisetifolia) }\end{array}$ & Tree uprooted \\
\hline 12.0 & - & $\begin{array}{l}\text { - } \quad \text { Batai Laut (Peltophorum Pterocarpum) } \\
\text { - } \quad \text { Mangga (Murr Mangifera Indica L) }\end{array}$ & Trunks snapped \\
\hline 8.9 & - & $\begin{array}{l}\text { - } \quad \text { Khaya (Khaya Anthotheca) } \\
\text { - } \quad \text { Rhu (Casuarina Equisetifolia) }\end{array}$ & Trunks snapped \\
\hline
\end{tabular}

Note: 1-minute gust speed, $10 \mathrm{~m}$ heigh 
Table 7. Damages scale

\begin{tabular}{|c|c|c|c|}
\hline $\begin{array}{c}\text { Intensity } \\
(\mathrm{m} / \mathrm{s})\end{array}$ & $\begin{array}{c}\text { Rainfall } \\
\text { (mm) }\end{array}$ & Physical & Potential damages \\
\hline 19.3 & - & $\begin{array}{ll}\text { - } & \text { Warehouse building } \\
\text { - } & \text { Low rise building } \\
\text { - } & \text { Walkway } \\
\text { - } & \text { Institutional building } \\
& \\
\text { - } & \text { Flag poles } \\
\end{array}$ & $\begin{array}{l}\text { Loss of roof covering material } \\
\text { Loss of roof covering material } \\
\text { Loss of roof covering material } \\
\text { Window damaged } \\
\text { Damaged truss } \\
\text { Loss of roof covering material } \\
\text { Collapsed }\end{array}$ \\
\hline 14.6 & - & $\begin{array}{ll}\text { - } & \text { Tree } \\
\text { - } & \text { Small retail building } \\
\text { - } & \text { School } \\
\text { - } & \text { Public house } \\
\text { - } & \text { Awning } \\
\end{array}$ & $\begin{array}{l}\text { Uprooted } \\
\text { Loss of roof covering material } \\
\text { Collapse of plaster ceiling } \\
\text { Loss of roof covering material } \\
\text { Damaged rafter } \\
\text { Window damaged } \\
\text { Damaged truss } \\
\text { Damaged }\end{array}$ \\
\hline 12.8 & Light & - $\quad$ Tree & Uprooted \\
\hline 12.2 & - & $\begin{array}{ll}\text { - } & \text { Apartment } \\
\text { - } & \text { Small retail building } \\
\end{array}$ & $\begin{array}{l}\text { Damaged roof } \\
\text { Damaged roof }\end{array}$ \\
\hline 12.0 & Moderate & - $\quad$ Tree & Uprooted \\
\hline 10.6 & - & - Wooden house & Collapse of exterior wall \\
\hline 10.4 & - & - $\quad$ Canopy & Collapsed \\
\hline 9.7 & - & $\begin{array}{l}\text { - Public house } \\
\text { - Porch }\end{array}$ & $\begin{array}{l}\text { Loss of roof covering material } \\
\text { Damaged roof } \\
\text { Collapse of plaster ceiling } \\
\text { Loss of roof covering material }\end{array}$ \\
\hline 9.0 & - & $\begin{array}{ll}\text { - } & \text { Tree } \\
\text { - } & \text { Wooden house } \\
\text { - } & \text { Wooden house }\end{array}$ & $\begin{array}{l}\text { Branches break } \\
\text { Loss of roof covering material } \\
\text { Damaged truss }\end{array}$ \\
\hline
\end{tabular}

Note: 1-minute gust speed, $10 \mathrm{~m}$ height

Potential physical damages: loss of roof covering material; cumulative rainfall: any damages home appliances and interior inside the building.

Cumulative rainfall: Light $(0.1-10.0 \mathrm{~mm})$; Moderate $(>10.0 \mathrm{~mm})$

\section{CONCLUSION}

Damages scale enables potential damages to be made known should windstorm occurred. Indirectly, through this information, the public may know whether they are safe in the surrounding area or otherwise. Hence, early preparation based on the worst-case scenario could be planned by local authorities and public in order to minimise the impact. The information that could be collected through the damages scale in mitigating impacts of windstorm occurrence provided reasons for this supporting tool to be utilised in windstorm disaster management in the country.

However, damages scale still needs to continuously be updated by adding and extending new damages to maintain the relevance of the scale to be applied in the future since some damages may not be found during the current time or at a certain area. Damages scale utilised 1-minute of gust speed for associated damages instead of 3 -seconds of gust/wind speed as existing damages scale due to interval gust speed observing time in Malaysia is 1 minute, while radar echoes imagery is 10 minutes respectively.

By maintaining gust speed at 1-minute, it is more easily to be applied in the development of windstorm-producing thunderstorms predictive models which uses radar imagery echoes as observational data. Establishing the damages scale is intended to serve as a supporting tool or an early warning system and not as an indicator of tornado intensity on a routine basis. There are two main challenges in updating and expanding the scale with new potential damage and its associated intensity. First, there are no open-source integrated database for windstorm damages. Even though, some government agencies had stored information of 
windstorm damages, however the information is not adequate and scientific enough but needs to be reassessed on site if that damage is to be an input in the scale. Furthermore, the interest for these damages differs from one agency to another. As an example, Department of Social Welfare store information of residential home damages only for loss compensation of the victims. While local authorities store information of tree damages for cost repair funding estimation.

Thus, this situation will create difficulties in collecting detail damage information to the parties with an interest to expand the scale. They must contact various agencies to which could be costly and time-consuming. Consistency error in damage assessment is another possibility. The second challenge is the availability of local conditions wind multiplier map. Currently, this type of map has yet to be found in any areas in Malaysia. Without this map, the actual associated intensity for a damage will most likely be impossible to determine. Wind speed from convective cloud will be affected by local land conditions when it reaches the land.
As a result, in for the ensure the practicality of the scale in the future, damages should continuously be assessed so that new potential damages could be added, and the hierarchy of the damages caused by intensity greater than $19.3 \mathrm{~m} / \mathrm{s}$ can be identified. On top of that the essential step that need to be taken in the development of the windstorm damage database which integrated all the related agencies and administrated by the expert society, and production of local conditions wind multiplier map all over the country. The database and map not only act as a tool for consistency in damage assessment, but also could accelerate the expanding of the scale.

This study discovered the relationship between windstorm damages and its associated intensity subjected to localised surrounding and construction in Malaysia that can be beneficial for local authorities and public in minimising the impacts of windstorm occurrence. Moreover, this study will help the researcher to uncover critical areas of windstorms and its mitigation measures that many researchers in the country were not able to explore yet. Thus, a new theory on how to assess the windstorm damages and determine its associated intensity may be arrived at.

\section{REFERENCES}

'Adila, NFRAS 2015, 'Kajian Awal Kejadian Puting Beliung di Malaysia' in Malaysia Meteorological Department (MMD), Ministry of Science and Innovation (MOSTI), no. 11.

Auld, H 2010, 'Disaster risk reduction under changing climate conditions: Roles for the national meteorological and hydrological services' in National Adaption Programmes of Action, New York.

Bachok, MF, Supiah, S \& Roslan, ZA 2012, 'Windstorm occurrences in Malaysia in the period of 2000 - 2012: An overview': Proceedings of the International Conference on Science, Technology and Social Sciences (ICSTSS), Malaysia.

Blong, R 2003, 'A review of damage intensity scales', in Natural Hazards, vol. 29, pp. 57-76.

Bunting, WF \& Smith, BE 1993, 'A guide for conducting damage surveys' in Oklahoma: NOAA Technical Memo.

Burroughs, WJ, Crowder, B, Robertson, T, Vallier-Talbot, E \& Whitaker, R 2003, 'Weather watching' in San Francisco: Fog City Press.
Deraman SNC, Wan Chik FA, Muhammad MKA, Noram IR, Taksiah, AM \& Ahamad, MSS 2014, 'Case study: Wind speed estimation of high-rise building using surface interpolation methods', Journal of Civil Engineering Research, vol. 4, pp. 145-148.

Dessens, J \& Snow, JT 1989, 'Tornadoes in France', Weather Forecasting, vol. 4, pp. 110-132.

Doswell, CA, Brooks, HE \& Dotzek, N 2009, 'On the implementation of the Enhanced Fujita Scale in the USA', Atmospheric Research, vol. 93, pp. 118-13.

Feuerstein, B, Groenemeijer, P, Dirksen, E, Hubrig, M, Holzer, AM \& Dotzek, N 2011, 'Towards an improved wind speed scale and damage description adapted for Central Europe', Atmospheric Research, vol. 100, pp. 547-564.

Fortin, M, Albrecht, A, Kohnle, U \& Ningre, F 2014, 'The Impact of Windstorm Damage in the Assessment of the Carbon Balance in Even-Aged Fagus sylvatica L. Stands', Forests, vol. 05, pp. 784-801. 
Freitas, JG \& Dias, JA 2013, '1941 windstorm effects on the Portuguese Coast. What lessons for the future?' in Proceedings 12th International Coastal Symposium (Plymouth, England), Journal of Coastal Research, Special Issue No. 65, pp. 714-719.

Fujita, TT 1971, 'Proposed characterisation of tornadoes and hurricanes by area and intensity', in Department of Geophysical Sciences, University Chicago.

Hung, CC 2010, 'The Impact of Global Warming on Strom and Strom Preparedness in Southeast Asia', in Kajian Malaysia, vol. 28, no. 1, pp. 53-82.

Houston, SH, Forbes, GS \& Chiu, AN 2002, 'Impacts of super typhoon Paka's (1997) winds on Guam: Meteorological and engineering perspectives', Natural Hazards Review, vol. 3, no. 2, pp. 1-9.

Kanak, J, Benko, M, Simon, A \& Sokol, A 2007, 'Case study of the 9 May 2003 windstorm in Southwestern Slovakia', Atmospheric Research, vol. 83, pp. 162-175.

Khairulmaini, OS 2007, 'Early warning systems do's and don'ts in environmental hazard management', in Informal Regional Ministerial Consultation on Climate and Extreme Weather Impacts and Predictability, Ministry of Science, Technology and Innovation.

Lee, S, Kim, J, Yohana, NM, Eko TP \& Sunarya 2017, 'Analysis of the Risk of Windstorm (angin puting beliung) in Indonesia', in Journal of the Wind Engineering Institute of Korea, pp. 1-8.

Malaysia Department of Irrigation and Drainage (2011). 'The Official Web of Public Infobanjir'. Available at http://www.forecast.water.gov.my

McDonald, JR, Mehta, KC, Smith, DA \& Womble, JA 2009, 'The Enhanced Fujita Scale: Development and implementation' in Proceeding of $5^{\text {th }}$ ASCE Forensic Engineering Congress, Washington, D. C, United States, 1114 November 2009, pp. 719-728.

Meaden, GT 1976, 'Tornadoes in Britain: Their intensities and distribution in space and time', Journal of Meteorology, vol. 1, pp. 242-251.

Potter, S 2007, 'Fine-tuning Fujita: After 35 years, a new scale for rating tornadoes takes effect', Weatherwise, vol. 6o, no. 2, pp. 64-71.

Roslan, ZA \& Hui, TK 1995, 'Rainfall energy production in relation to soil erosion': in Proceeding of Kursus Lanjutan Penilaian Sumber Air '95 (KLPSA'95), Johor, Malaysia, 2022 November 1995.
Sallis, PJ, Claster, W \& Hernandez, S 2011, 'A machinelearning algorithm for wind gust prediction', Computers and Geosciences, vol. 37, no. 9, pp. 1337-1344.

Schelhaas, MJ, Nabuurs, GJ \& Schuck, A 2003, 'Natural disturbances', in the European forests in the 19th and 2oth centuries. Globle Change Biology, vol. 9, pp. 1620-1633.

Wakimoto, RM 2001, 'Convectively driven high wind events: Severe convective storms', Meteorological Monographs, vol. 50, pp. 255-298.

Webb, JD, Elsom, DM \& Meaden, GT 2009, 'Severe hailstorms in Britain and Ireland, a climatological survey and hazard assessment', Atmospheric Research, vol. 93, no. 1 , pp. 587-606.

Zakaria, NH, Salleh, SA, Asmat, A \& Islam, MA 2019, 'Seasonal Windstorm Pattern and Damages in Peninsular

Malaysia 2018', in Proceeding of 4th International Conference on Research Methodology for Built Environment and Engineering, Chulalongkorn University, Thailand, 24-25 April 2019.

Zielinski, GA 2002, 'A classification scheme for winter storms in the Eastern and Central United States with an Emphasis on Nor'easters', in Bulletin of the American Meteorological Society, vol. 83, no. 1, pp. 37-51. 